amidopyrine greatly increased pentose excretion in such a person. We have been unable to trace any Jewish ancestry in the present case, but it is possible that this patient has a genetic predisposition to pentosuria which renders her more susceptible to this effect of glutethimide.

The osteomalacia in this patient was not due to malabsorption or renal disease. The dietary intake of vitamin $\mathrm{D}$ was assessed as being definitely above $70 \mathrm{IU} /$ day, which is regarded by Dent and Smith (1969) as the lower limit of normal. Hepatic enzymeinduced changes in vitamin $\mathrm{D}$ metabolism may render such a marginal intake inadequate. In this case the metabolism of ${ }^{3} \mathrm{H}$ vitamin $\mathrm{D}_{3}$ was faster when the patient was in the induced state (fig. 4). This occurred despite the therapeutic dose of $0.5 \mathrm{mg}$ of vitamin $\mathrm{D}_{3}$ administered between the two studies, which would have increased the pool size of vitamin $\mathrm{D}$ and thus favour a relatively slower apparent metabolism of the isotope tracer. The greater pool size may have effectively masked a decrease in ${ }^{3} \mathrm{H}-25-\mathrm{OHD}_{3}$ half-life in the second study. The paradox of an increased formation of an active metabolite $\left(25-\mathrm{OHD}_{3}\right)$ resulting in a postulated decrease in biological activity of vitamin $\mathrm{D}$ may be due to an associated increase in excretion of further metabolites of vitamin $\mathrm{D}$ in the bile. This has been shown in enzyme-induced animals by Silver et al. (1972b). Unless there was an adequate intake of vitamin D this would ultimately deplete vitamin D stores, and this is likely to be the mechanism whereby glutethimide produced oesteomalacia in this case. This complication of chronic hypnotic ingestion seems to be a potential risk in any patient receiving a long-term barbiturate-like drug, particularly if in association with a poor diet. Our experience with this patient suggests that the use of nitrazepam should not give rise to this problem.

We would like to thank Dr. G .R. Clarke, of the Department of Rheumatology and Physical Medicine, St. Thomas's Hospital, for referring the case. We are grateful to the following people for the various measurements on the patient: Dr. S. E. Smith, antipyrine; Professor R. V. Brooks, 6 $\beta$-hydroxycortisol; Dr. I. S. I. Menzies, xylulose; Mr. D. A. Stewart (King's College Hospital), D-glucaric acid; Dr. R. R. McSwiney, 5-nucleotidase and routine biochemistry; Dr. L. Ellis, gamma-glutamyl transpeptidase and leucine aminopeptidase; and Dr. P. J. N. Howarth (King's College Hospital), alkaline phosphatase isoenzymes. We are indebted to Dr. G. R. Thompson (Royal Postgraduate Medical School) for his helpful advice and encouragement.

\section{References}

Bieger, R., De Jonge, H., and Loeliger, E. A. (1972). Clinical Pharmacology and Therapeutics, 13, 361 .

Breckenridge, A., Orme, M. L'E., Thorgeirsson, S., Davies, D. S., and Clinical Science, 40, 351.

Brodie, B. B., Axelrod, J., Soberman, R., and Levy, B. B. (1949). Fournal

of Biological Chemistry, 179, 25.
Burns, J. J., Evans, C., and Trousof, N. (1957). Fournal of Biological Chemistry, 227, 785 .

Campbell, D. M. (1962). Biochemical fournal, 82, 34p

Canapa-Anson, R., and Rowe, D. J. F. (1970). Fournal of Clinical Pathology, 23, 499.

Conney, A. H. (1967). Pharmacological Reviews, 19, 317

Corn, M. (1966). Thrombosis et Diathesis Haemorrhagica, 16, 606.

Dent, C. E., Richens, A., Rowe, D. J. F., and Stamp, T. C. B. (1970). British Medical fournal, 4, 69 .

Dent, C. E., and Smith, R. (1969). Quarterly fournal of Medicine, 38, 195.

Evans, C., Conney, A. H., Trousof, N., and Burns, J. J. (1960). Biochimica et Biophysica Acta, 41, 9.

Greenlaw, R. et al. (1972). Clinical Research, 20, 56

Hahn, T. J., Birge, S. J., Scharp, C. R., and Avioli, L. V. (1972). Fournal of

Clinical Investigation, 51, 741.
Hunter, J., Maxwell, J. D., Carella, M., Stewart, D. A., and Williams, R. (1971). Lancet, 1, 572.

Hyde, R. D., Vaughan Jones, R., McSwiney, R. R., and Prunty, F. T. G. (1960). Lancet, 1, 250.

Kato, R., and Chiesara, E. (1962). British fournal of Pharmacology, 18, 29. Kruse, R. (1968). Monatsschrift für Kinderheilkunde, 116, 378.

Kuntzman, R., Jacobson, M., Levin, W., and Conney, A. H. (1968). Biochemical Pharmacology, 17, 565 .

Lawson, D. E. M., Frazer, D. R., Kodicek, E., Morris, H. R., and Williams, D. H. (1971). Nature, 230, 228.

McCance, R. A., and Widdowson, E. M. (1967). Medical Research Council. Special Report Series No. 297

Margolis, J. I. (1929). American fournal of the Medical Sciences, 177, 348.

Mawer, E. B., and Backhouse, J. (1969). Biochemical fournal, 112, 255.

Nagel, W., Willig, F., and Schmidt, F. H. (1964). Klinische Wochenschrift, 42, 447.

Ponchon, G., and De Luca, H. F. (1969). Fournal of Clinical Investigation, 48,1273 .

Prunty, F. T. G., McSwiney, R. R., and Clayton, B. E. (1953). Fournal of Clinical Investigation, 13, 1480

Richens, A., and Rowe, D. J. F. (1970). British Medical fournal, 4, 73.

Rosalki, S. B., Tarlow, D., and Rau, D. (1971). Lancet, 2, 376.

Santangelo, R. P., Fidler, S. M., Mackin, J. F., and Canary, J. J. (1972). Fournal of Clinical Investigation, 51, 84a.

Schmid, F. (1967). Fortschritte der Medizin, 85, 381.

Silver, J., Neale, G., Davies, D. S., Breckenridge, A., and Thompson, G. R. (1972 a). Clinical Science, 42, $12 \mathrm{p}$.

Silver, J., Quill, H., Neale, G., and Thompson, G. R. (1972 b). Clinical

Szasz, G. (1969). Clinical Chemistry, 15, 124.

\title{
Radioimmunoassay of Triiodothyronine in Unextracted Human Serum
}

\author{
R.-D. HESCH, DAVID EVERED
}

British Medical fournal, 1973, 1, 645-648

\section{Summary}

Serum triiodothyronine ( $T-3)$ concentrations have been estimated by radioimmunoassay using unextracted serum. The serum $T-3$ concentrations have been shown to be similar in two separate European populations (0.76-1.67 $\mathrm{ng} / \mathrm{ml}$ ). Raised T-3 values have been observed in all subjects with

Medizinische Universitatsklinik, Göttingen, Germany

R.-D. HESCH, M.D., Endocrinologist

Department of Medicine, University of Newcastle upon Tyne DAVID EVERED, M.D., M.R.C.P., Wellcome Senior Research Fellow in Clinical Science hy perthyroidism. Low values are seen in hypothyroidism although there is some overlap with the normal range. There is a good correlation between serum T-3 and serum thyroxine ( $T-4)$ concentrations, and estimation of $T-3$ seems likely to prove a practical and reliable test of thyroid function.

\section{Introduction}

The major fraction of organic iodine in the circulation is in the form of L-thyroxine (T-4). Although significant amounts of 3,5, 3'-triiodo-L-thyronine (T-3) are present (Gross and Pitt-Rivers, 1952), relatively little is known of the physiological importance of this hormone. A number of techniques have been used to measure the low concentrations of T-3 present in the serum but most of these have suffered from 
major technical limitations. These have included radiochemical techniques and chemical methods in which the catalytic activity of T-3 is utilized. The results from both of these techniques have always been open to question because of the technical limitations. More recently a number of new techniques have been devised (Sterling et al., 1969) which are much more precise but which are very time consuming. The accuracy of these techniques has also been questioned on the basis of the conversion of T-4 to T-3 during the assay procedure (Larsen, 1971a). The production of specific antibodies to T-3 was first described by Brown et al. (1970a), and more recently techniques for the measurement of $\mathrm{T}-3$ in unextracted serum have been reported (Chopra et al., 1971; Lieblich and Utiger, 1971; Mitsuma et al., 1971; Larsen, 1972a).

\section{Methods}

Preparation of Antiserum.-Specific T-3 antisera were raised by the serial injection of T-3-methyl ester hydrochloride conjugated to bovine serum albumin (Hesch and Huefner, 1972). Antisera were raised in each of the three rabbits immunized. Assay._- ${ }^{25}$ I-labelled T-3 $(80-125 \mathrm{mCi} / \mathrm{mg})$ was obtained from Byk-Mallinckrodt, St. Louis, U.S.A., or from the Radiochemical Centre, Amersham (30-50 mCi/mg). Human serum free of T-3 was prepared by mixing normal serum with Amberlite resin CG400, type 11, 200 mesh (Rhom and Haas Co.), $1 \mathrm{ml}$ serum to $100 \mathrm{mg}$ resin for 30 minutes after warming to $40^{\circ} \mathrm{C}$. Standard solutions of T-3 were prepared with T-3 obtained from various commercial sources-for example, Sigma Chemical Co., St. Louis, and Georg Henning, Chem. Pharm. Werk, G.m.b.H., Berlin-and these were shown by experiment to give identical standard curves. The assay procedure carried out in the two centres was as fellows.

Solutions.-Buffer: sodium phosphate 0-05 mol/1. pH 7.6 with human serum albumin. Standard solutions: ranging from 0.500 pg T-3/assay tube. Blocking agent: merthiolate $1: 1,000$ in tris/ $\mathrm{HC1} \quad 0.05 \mathrm{~mol} / 1 . \mathrm{pH} \mathbf{9 . 0}$ (Göttingen); sodium salicylate $5 \mathrm{mg} / 0.1$ $\mathrm{ml} 0.05 \mathrm{~mol} / 1$. sodium phosphate (Newcastle). Tracer solution: $15-30 \mathrm{pg}{ }^{125}$ I-labelled T-3 (Göttingen); 100 pg ${ }^{125}$ I-labelled T-3 (Newcastle). Antibody solution: rabbit anti-T-3 serum diluted in $0.9 \%$ sodium chloride. Dextran/charcoal: $0.15 \mathrm{~g}$ dextran T70 to $1 \mathrm{~g}$ Norit $\mathrm{A}$ in $0.05 \mathrm{~mol} / 1$. sodium phosphate buffer $(100 \mathrm{ml})$.

\section{Assay Procedure}

Göttingen

$0.02-0.1 \mathrm{ml}$ standard or unknown serum.

$0.05 \mathrm{ml}{ }^{125} \mathrm{I}$-labelled $\mathrm{T}-3$.

$0.05 \mathrm{ml}$ antiserum (final dilu-

tion) $1 / 20,000$.

$0.5 \mathrm{ml}$ buffer with merthiolate.
Newcastle

$0.5 \mathrm{ml}$ buffer (with or without standard).

$0.1 \mathrm{ml} \mathrm{T}-3$ free or unknown serum.

$0.1 \mathrm{ml}$ sodium salicylate.

$0.1 \mathrm{ml}{ }^{125} \mathrm{I}$-labelled T-3.

$0.1 \mathrm{ml}$ antiserum (final dilution) $1 / 12,600$.

Incubate overnight at $4^{\circ} \mathrm{C}$ with appropriate blanks.

Add $0.5 \mathrm{ml}$ dextran $/$ charcoal to each.

Centrifuge after exactly five minutes.

Decant supernatant and count the charcoal residue in an automatic well scintillation counter.

\section{Results}

Standard Curve.-The addition of increasing quantities of $\mathrm{T}-3$ to the reaction mixture leads to progressive decreases in the proportion of ${ }^{125}$ I-labelled $\mathrm{T}-3$ bound to the antiserum (fig. 1). At the antiserum concentration used it was found that $60-75 \%$ of the labelled T-3 was bound. The addition of stable T-3 to unextracted serum and the measurement of serial dilutions of hyperthyroid sera produce displacement curves which can be superimposed on the standard curve. It was found that equilibration was complete within 2.5 hours

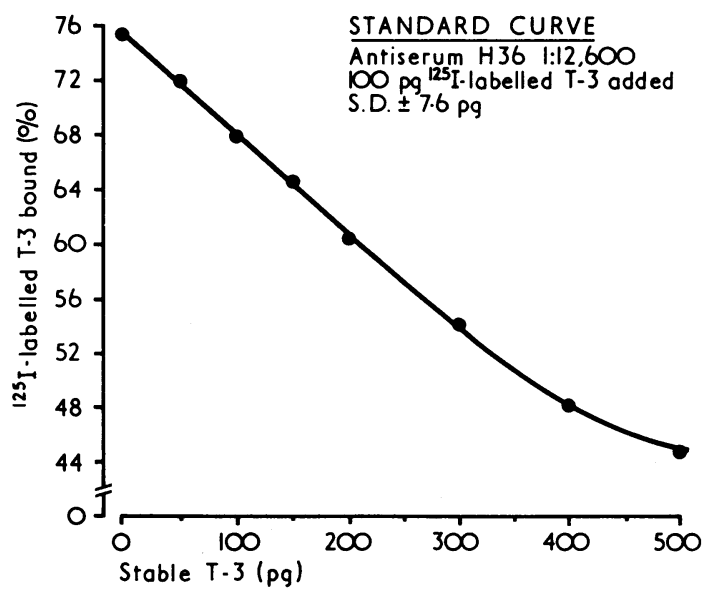

FIG. 1-Increasing quantities of $T-3$ to reaction mixture leading to progressive decreases in proportion of ${ }^{125} \mathrm{I}$-labelled T-3 bound to antiserum.

at $4^{\circ} \mathrm{C}$ although the incubation was generally carried out overnight for reasons of convenience.

Precision.-All standards and unknowns were prepared in triplicate. The standard deviation was calculated for each assay and was found to vary between 7 and 10 by $10^{-12} \mathrm{~g}$. This figure did not vary significantly through the range of concentrations observed during routine radioimmunossays. The S.D. was therefore $5.5 \%$ of the mean of the T-3 concentrations in normal subjects.

Reproducibility.-Samples covering a range of T-3 concentrations were assayed in consecutive assays. The S.D. was found to be 11 by $10^{-12} \mathrm{~g}$. This figure did not vary significantly through the range of concentrations observed. Thus the S.D. was $8.7 \%$ of the mean of the T-3 concentrations in normal subjects.

Specificity.-The cross-reactivity with T-4 was found to be less than $0.1 \%$. Thus the presence of a normal concentration of $\mathrm{T}-4$ in human serum (about 80 by $10^{-9} \mathrm{~g} / \mathrm{ml}$ ) would lead to an artefactual rise of serum T-3 concentration of less than 0.08 by $10^{-9} \mathrm{~g} / \mathrm{ml}$. There was no measurable cross-reactivity with monoiodotyrosine or diiodotyrosine but there was $30 \%$ cross-reactivity with triiodothyracetic acid.

\section{SERUM T-3 CONCENTRATIONS IN NORMAL SUBJECTS}

The serum T-3 concentration was estimated in 54 adult euthyroid subjects in Newcastle (fig. 2). These were members of hospital staff, patients who were not suspected of having thyroid disease, and patients with suspected thyroid disease in whom all measurements of thyroid function were normal and who responded normally to intravenous thyrotrophin-releasing hormone according to the criteria of Ormston et al. (1971). The mean serum T-3 concentration in these subjects was $1.26 \mathrm{ng} / \mathrm{ml}$ (S.D. $\pm 0.23 \mathrm{ng} / \mathrm{ml}$ ) observed range $0.76-1.67 \mathrm{ng} / \mathrm{ml}$. The total serum $\mathrm{T}-3$ concentration was measured in 130 euthyroid subjects in Göttingen who were selected on the same basis. The mean serum T-3 concentration in these subjects was $1.20 \mathrm{ng} / \mathrm{ml}$ (S.D. \pm 0.30 $\mathrm{ng} / \mathrm{ml}$ ) and the observed range was $0 \cdot 80-1 \cdot 50 \mathrm{ng} / \mathrm{ml}$.

\section{SERUM T-3 CONCENTRATION IN HYPOTHYROIDISM}

The serum T-3 concentration was estimated in 39 subjects with overt hypothyroidism in Newcastle (Evered and Hall, 1972). The mean value in these subjects was $0.48 \mathrm{ng} / \mathrm{ml}$, observed range from $0-1.07 \mathrm{ng} / \mathrm{ml}$, and it will be observed that there was some overlap with the normal group (fig. 2). Similar values were obtained in 26 subjects with overt hypothyroidism who were studied in Göttingen. The range of 


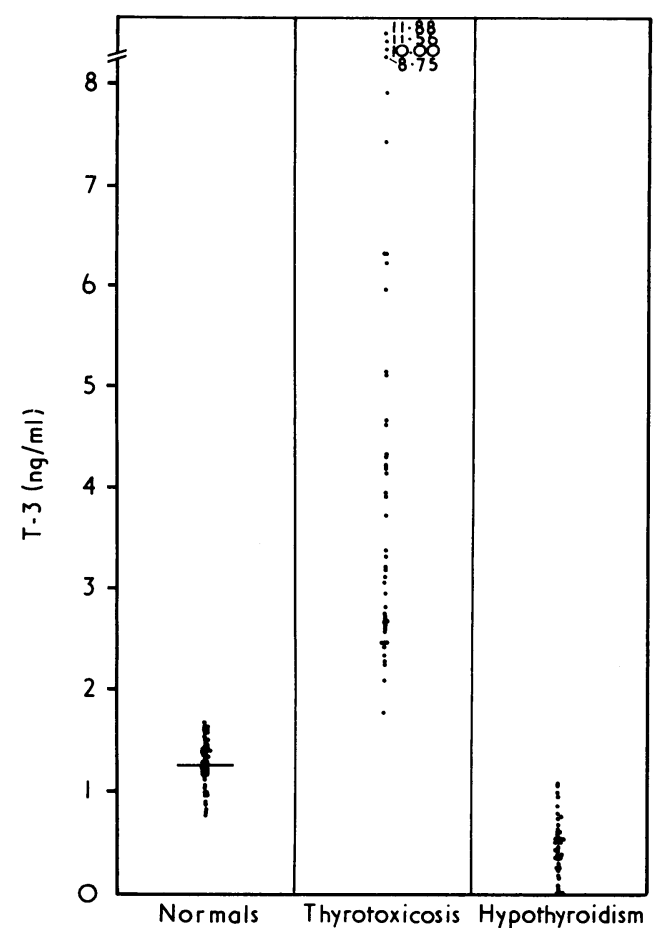

FIG. 2-Estimation of T-3 concentration in 54 normal, 47 hyperthyroid, and 39 hypothyroid subjects.

values recorded lay between 0 and $0.90 \mathrm{ng} / \mathrm{ml}$ and again some overlap with the normal subjects was noted.

\section{SERUM T-3 CONCENTRATIONS IN HYPERTHYROIDISM}

The serum T-3 concentration was estimated in 47 subjects with unequivocal clinical and biochemical evidence of hyperthyroidism. The values observed ranged from 1.77 to 11.88 $\mathrm{ng} / \mathrm{ml}$. There was no overlap with the normal group and only one subject in this group was found to have a serum T-3 concentration of less than $2 \mathrm{ng} / \mathrm{ml}$ (fig. 2). Rather higher values were observed in 60 hyperthyroid subjects studied in Göttingen in whom the values ranged from 3.0 to $30 \mathrm{ng} / \mathrm{ml}$.

\section{CORRELATION OF T-3 AND T- 4 CONCENTRATIONS}

There is in general a good correlation between serum T-3 concentration and the serum $T-4$ concentration (Thyopac-4, Radiochemical Centre, Amersham). Estimation of the total

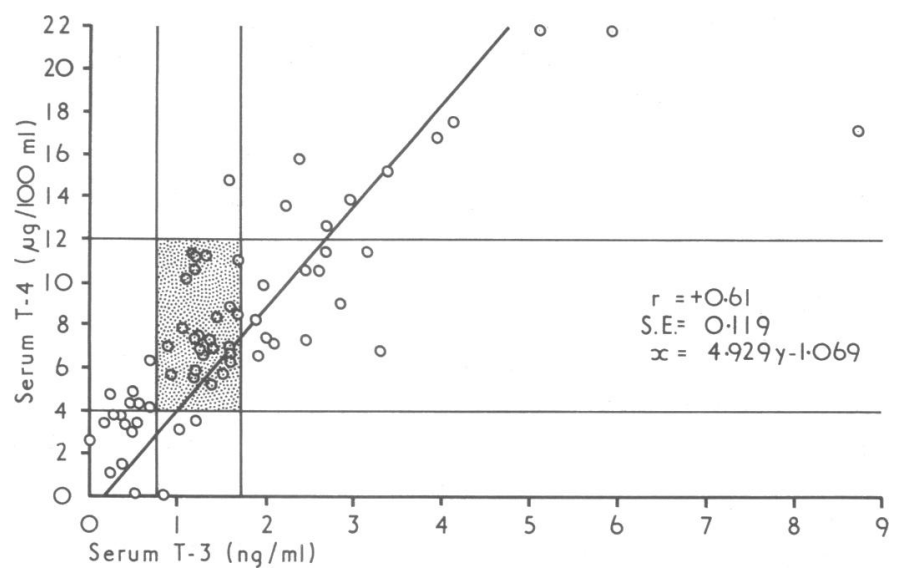

FIG. 3-Estimation of total T-3 and T-4 concentrations on a single serum sample of 71 subjects. concentration of both thyroid hormones was made on a single serum sample in 71 subjects (fig. 3 ). The correlation coefficient was +0.61 despite the inclusion of nine subjects with T-3 thyrotoxicosis.

\section{Discussion}

The measurement of serum T-3 concentration has always posed problems on account of the very low concentration of this hormone in the plasma and also as a result of the relatively high concentration of $\mathrm{T}-4$ in the serum. Early techniques thus required lengthy extraction and separation procedures. The production of specific antibodies to T-3 was first described by Brown et al. (1970a) and they developed a satisfactory assay system on extracted serum (Brown et al., $1970 \mathrm{~b}, 1971)$. This system first showed that serum $\mathrm{T}-3$ concentrations measured by immunological techniques appeared to be substantially lower than those reported by Sterling $e t$ al. (1969). The specificity and sensitivity of this assay appear to be similar to those reported here. The range of values reported in normal subjects $(0.75-1.6 \mathrm{ng} / \mathrm{ml})$ is similar to the range observed in the present study (Brown et al., 1971). The development of radioimmunoassay procedures on unextracted serum has, however, been hampered by the presence of thyroxine-binding globulin in the serum, which also binds T-3. This problem is overcome by the use of salicylates (sodium salicylate and merthiolate) which inhibit the binding of T-3 by thyroxine-binding globulin and also by thyroxinebinding prealbumin (Larsen, 1971b; Larsen, 1972b). The concentration of salicylate used in this assay is sufficient to completely inhibit the binding of $\mathrm{T}-3$ by the serum proteins. It has thus been possible to develop a rapid, sensitive, and precise assay system for the measurement of $\mathrm{T}-3$ in unextracted serum. Other workers have used diphenylhydantoin (Lieblich and Utiger, 1971), tetrachlorothyronine (Mitsuma et al., 1971), or thyroxine (Chopra et al., 1971) to block the binding of T-3 by the serum proteins. The inhibition of T-3 binding by the serum proteins has been described in detail by Huefner and Hesch (1973).

Full details of the characteristics of the antisera used have also been reported (Hesch and Huefner 1972). The present antisera appear to compare very favourably with assays reported by other workers (Chopra et al., 1971; Mitsuma et al., 1971; Larsen, 1972a) in that incubation periods are much shorter. The sensitivity of these assays appear to be similar to those reported by Missuma et al. (1971) and Larsen (1972a). The sensitivity of the assay described by Chopra (1971) appears to be very low in that the detection threshold is as high as $1 \mathrm{ng} / \mathrm{ml}$ and thus this assay is unable to distinguish reliably between normal and hypothyroid concerntrations of $\mathrm{T}-3$.

The mean serum $\mathrm{T}-3$ concentration in normal subjects is found to be $1.26 \mathrm{ng} / \mathrm{ml}$ (S.D. $\pm 0.23 \mathrm{ng} / \mathrm{ml}$ ) in Newcastle and $1.20 \mathrm{ng} / \mathrm{ml}$ (S.D. $\pm 0.30 \mathrm{ng} / \mathrm{ml}$ ) in Göttingen using unextracted serum. The values are similar to those reported by Mitsuma et al. (1971) $(1.38 \pm 0.23 \mathrm{ng} / \mathrm{ml})$ and by Larsen (1972a) $(1.10 \pm 0.25 \mathrm{ng} / \mathrm{ml})$ and rather lower than the mean value of $1.50 \mathrm{ng} / \mathrm{ml}$ reported by Lieblich and Utiger (1971). These values are substantially lower than those reported by workers using the technique of Sterling et al. (1969), and it seems probable that the higher values recorded by this method can be accounted for by the conversion of T-4 to T-3 during the assay procedure (Larsen, 1971a).

The serum T-3 concentrations observed in hypothyroidism are essentially similar to those reported by other workersthe mean value of $0.48 \mathrm{ng} / \mathrm{ml}$ being slightly higher than that noted by Larsen (1972a) and lower than that reported by Mitsuma (1971). Like Larsen (1972a) we have also observed some overlap of values in hypothyrodism with those seen in euthyroid subjects. Mitsuma and his colleagues (1971) noted no such overlap. It is impossible, however, to compare the 
two groups of parents directly since detailed diagnostic information is lacking in their reports. A similar overlap in protein bound iodine and free thyroxine index is also observed between patients with hypothyroidism and normal subjects (Evered et al., 1973).

The estimation of serum T-3 concentration appears to discriminate well between normal subjects and those with hyperthyroidism in all series and the range of T-3 concentrations appears to be similar in all the groups studied by all workers with mean values between 4.2 and $5.2 \mathrm{ng} / \mathrm{ml}$. Subjects with minor degrees of hyperthyroidism, however, appear to have been excluded in the preliminary studies of serum T-3 concentrations reported. The discriminant value of this estimation in the diagnosis of hyperthyroidism remains to be definitely established. Raised serum T-3 concentrations have also been observed in other clinical situations which will be described elsewhere.

There is the generally expected correlation between serum $T-4$ and T-3 concentrations, and the relation between the concentrations of the two thyroid hormones in the serum is very similar to that reported by Larsen (1972a). The only general deviation from this correlation is seen in the subjects with T-3 thyrotoxicosis, and also in some other clinical states.

Part of this work was carried out during the tenure of a Wellcome Senior Research Fellowship in Clinical Science by D.E. It is a pleasure to acknowledge financial support given by the Scientific and Research Committee of the Newcastle University Hospital Group and the Medical Research Council.

\section{References}

Brown, B. L., Ekins, R. P., Ellis, S. M., and Reith, W. S. (1970a). Nature, 226, 359.

Brown, B. L., Ekins, R. P., Ellis, S. M., and Reith, W. S. (1970b). In In-vitro Procedures with Radioisotopes in Medicine, p. 569. Vienna, I.A.E.A.

Brown, B. L., Ekins, R. P., Ellis, S. M., and Williams, E. S. (1971). In Further Advances in Thyroid Research, ed. K. Fellinger and R. Höfer, p. 1107. Vienna, Academy of Medicine.

Chopra, I. J., Solomon, D. H., and Beall, G. N. (1971). fournal of Clinical Investigation, $50,2033$.

Evered, D., and Hall, R. (1972). British Medical fournal, 1, 290.

Evered, D., and Hall, R. (1972). British Medical fournal, 1, 290.
Evered, D. C., Ormston, B. J., Smith, P. A., Hall, R., and Bird, T. (1973). British Medical fournal. In press.

British Medical fournal. In press.
Gross, J., and Pitt-Rivers, R. (1952). Lancet, 1, 439.

Hesch, R. D., and Huefner, M. (1972). Acta Biologica et Medica Germanica, 28,861 .

Huefner, M., and Hesch, R. D. (1973). Submitted for publication.

Larsen, P. R. (1971a). Metabolism, 20, 609.

Larsen, P. R. (1971b). Metabolism, 20, 976.

Larsen, P. R. (1972a). Fournal of Clinical Investigation, 51, 1939.

Larsen, P. R. (1972b). Journal of Clinical Investigation, 51, 1125.

Lieblich, J. M., and Ưtiger, R. D. (1971). Fournal of Clinical Investigation, 50, 60a.

Mitsuma, T., Nihei, N., Gershengorn, M. C., and Hollander, C. S. (1971). fournal of Clinical Investigation, 50, 2679.

Ormston, B. J., Garry, R., Cryer, R. J., Besser, G. M., and Hall, R. (1971).

Ormston, B.
Lancet, 10 .
Sterling, K., Bellabarba, D., Newman, E. S., and Brenner, M. A. (1969). fournal of Clinical Investigation, 48, 1150 .

\title{
Vitamin $B_{12}$ Malabsorption after Cobalt Teletherapy for Carcinoma of the Bladder
}

\author{
M. P. MCBRIEN
}

British Medical fournal, 1973, 1, 648-650

\section{Summary}

After cobalt teletherapy for carcinoma of the bladder, eight out of 14 consecutively admitted patients were shown to have malabsorption of vitamin $B_{12}$, though none had developed a megaloblastic anaemia. Despite lack of symptoms this group of patients is at risk after radiotherapy.

\section{Introduction}

Cobalt teletherapy is an accepted method of treating infiltrating carcinoma of the bladder. The small bowel lies in the field of irradiation and since it is highly radiosensitive intestinal complications after treatment sometimes occur. Those of stenosis, obstruction, perforation, or fistulation of the small bowel are well known, and from animal and clinical observations it has been realized for some time that malabsorption can also occur (Dodds and Webster, 1924; Martin and Rogers, 1924; Buchwald, 1931; Salvesan and Kobro, 1939; Moss, 1957; Scudamore and Green, 1959; Sauer, 1959; Wood et al., 1963; Duncan and Leonard, 1965). Irradiated bowel has frequently been observed at laparotomy to be rigid and thickened and histologically there is mucosal atrophy and submucosal

Department of Urology, St. Thomas's Hospital, London SE1 7EH M. P. MCBRIEN, M.B., F.R.C.S., Senior Surgical Registrar fibrosis (Halls, 1965). The terminal ileum lies in the pelvis, is the most frequently involved segment of gut (Dodge, 1969), and is wholly responsible for $B_{12}$ absorption (Booth and Mollin, 1959). Surprisingly few cases of malabsorption of this vitamin after pelvic irradiation have been recorded. A number of patients with carcinoma of the bladder at St. Thomas's Hospital who were referred for cobalt teletherapy were studied to assess the degree to which malabsorption of vitamin $B_{12}$ occurred after this form of treatment.

\section{Patients and Methods}

The patients were interviewed when they attended hospital for follow-up cystoscopy between December 1969 and May 1970. They had all had cobalt teletherapy for stage II or stage III carcinoma of the bladder, each receiving a tumour and tissue maximum dose of $3,600 \mathrm{r}$ and a minimum dose of 3,100 r. Most were given six treatments in 18 days using a four-field technique-anterior and posterior with two laterals-to cover the whole true pelvis. A history was taken and they were examined clinically for signs of metastatic disease or abdominal abnormality.

The haemoglobin and serum $B_{12}$ concentrations and the plasma urea were measured.

The absorption of vitamin $B_{12}$ was estimated by the Schilling test modified by the addition of intrinsic factor. A dose of 0.5 $\mu \mathrm{g}{ }^{57} \mathrm{Co} \mathrm{B}_{12}$ was given by mouth with 1 U.S.N.F. unit of hog intrinsic factor (supplied by Radiochemical Centre, Amersham). One and a half hours later a flushing dose of $1,000 \mu \mathrm{g}$ of vitamin $B_{12}$ was given intramuscularly. The 24-hour urine specimen was 